\title{
MAİŞET VE MEVACIBB: EGE ADALARINDAKİ OSMANLI KALELERİNDE GEÇİM MÜCADELESİ
}

\author{
Orçun Nalezen*
}

\begin{abstract}
Öz
Makalede Ege Adalarındaki Osmanlı kalelerinde XVI. yüzyıl sonu ile XVII. yüzyıl başlarında görev yapan askerlerin verdikleri geçim mücadelesine odaklanılmaktadır. Kalede görev yapmayı tercih eden bir reaya başka her türlü mesleki ve gelir getirici sivil uğraştan kopmuş oluyordu. Dolayısıyla görev yaptıkları bölgenin sahip olduğu iş gücü ve insan kaynağının parçası olup kalede görev yapan bu bireyler, müdafaası kalenin varlığına terk edilmiş olan sahada yaşayan doğrudan vergi mükellefi olan reayanın arasından çekilmiş oluyorlardı. Kalelerde görev yapan askerlerin karşı karşıya kaldığ1 ekonomik sıkıntılar bu bağlamda ele alınmaktadır. Askerlerin yaşadıkları mali sorunların iki temel sebebi vardı. Bunlardan ilki asker maaşları ile enflasyon arasındaki kopuş, ikincisi ise gedik usulsüzlüklerinin yol açtı̆̆1 gelir adaletsizliğiydi. Ayrıca kalede görevli askerleri etkisi altına alan ekonomik sıkıntıların sebepleri ile yaşanmakta olan sorunlara karşı karar alıcılar tarafindan geliştirilen çözüm arasındaki ilişki gözler önüne serilmektedir. Çözüm için atılan adımlar üzerinden sorunların kökenine yönelik bakış açısı ele alınmaktadır. Ege Adaları'ndaki Osmanlı kaleleri, Akdeniz sathında takip edilen kapsamlı stratejik hedeflere hizmet veriyordu. Dolayısıyla askerlerin yaşadığ1 maddi sorunların çözümü yalnız insani değil, askerî ve statejik önem arz ediyordu.
\end{abstract}

Anahtar Kelimeler: Ege, Osmanlı, kaleler, maaş, geçim.

\section{Living and Salary: The Life Struggle in the Ottoman Fortress in Aegean Islands}

\begin{abstract}
In the article, the Ottoman castles in the Aegean Islands, XVI. century to the end of the XVII. It focuses on the livelihood struggle of the soldiers who served at the beginning of the century. A reaya who chose to serve in the castle was detached from all other professional and income-generating civil pursuits. Therefore, these individuals, who are part of the workforce and human resources of the region they work in, and who work in the castle,
\end{abstract}

* Arş.Gör.Dr., Kastamonu Üniversitesi Fen Edebiyat Fakültesi Tarih Bölümü, 37150, Kuzeykent, Merkez - Kastamonu / Türkiye, orcunnalezen@gmail.com, Orcid ID: https://orcid.org/0000-00031149-3261. 
were withdrawn from the direct taxpayer people living in the area whose defence was left to the existence of the castle. The economic problems faced by the soldiers serving in the castles are discussed in this context. There were two main reasons for the financial problems experienced by the soldiers. The first of these was the rupture between military salaries and inflation, and the second was the income inequality caused by breach irregularities. In addition, the relationship between the reasons of the economic problems affecting the soldiers in the castle and the solution developed by the decision-makers against the problems experienced are revealed. The perspective on the root of the problems is discussed through the steps taken for the solution. Ottoman fortresses in the Aegean Islands served comprehensive strategic objectives pursued on the Mediterranean. Therefore, the solution of the material problems experienced by the soldiers was not only of humanitarian but also of military and strategic importance.

Keywords: Aegean, Ottoman, fortress, salary, life struggle.

\section{Giriş ${ }^{1}$}

Maaş, işin doğası gereği istihdam süreçlerinin en kritik unsurlarından biridir. Nitelikli emeği elde etmenin ve elde tutmanın yollarından biri doğru maaş politikası takip etmekten geçer. Bu husus, tarihin bir noktasında, ilk defa birinin kendi emeğine paha biçmesinden itibaren hiç değişmemiş olmalıdır. Bir meslek olarak askerlik de bireylerin yeteneklerini, emeklerini hatta canlarını sermaye ederek gelir elde ettikleri bir alandır. Bu makalede, Ege'deki Osmanlı kalelerinin bedenlerinde sürekli olarak ufku tarayan, bir topun ardında nöbet tutan askerlerin verdikleri geçim mücadelesi ele alınacaktır. Yakın döneme değin gerçekleştirilmiş olan çalışmalar sayesinde Erken Moden Dönemde Ege Adalarında Osmanlı Devleti tarafından teşkilatlandırılan idarî ${ }^{2}$ ve askerî yapılanma ${ }^{3}$ ile adalardaki sosyal ve ekonomik kurgu ${ }^{4}$ hakkında hatırı sayılır miktarda tarihsel veri ortaya konulmuş

1 Makaleyi okuyarak, tavsiyelerde bulunma nezaketi gösteren Hocam Prof. Dr. Yasemin Demircan'a teşekkür ederim.

2 Ege Adalarındaki idarî teşkilatlanma hakkında bk. Ege Adalarmm Egemenlike Devri Tarihçesi, (ed. Cevdet Küçük), Ankara 2001; Türk Hâkimiyetinde Ege Adalarn'nn Yönetimi, (ed. Cevdet Küçük), Ankara 2002; Ege Adalarinnn İdarî, Malîve Sosyal Yapısı, (ed. İdris Bostan), Ankara 2003.

3 Ege Adalarındaki Osmanlı kaleleri hakkında kapsamlı bir değerlendirme için bk. Orçun Nalezen, Ege Adalarnda Osmanl Hâkimiyetinin Kurulmasinda ve Sürdürülmesinde Kalelerin Rolü, Gazi Üniversitesi Sosyal Bilimler Enstitüsü, Doktora Tezi, Ankara 2021.

4 İçerisine asker konuşlandırılmış tahkimalatlara ev sahipliği yapan adalardaki toplumsal ve ekonomik durum hakkında bilgi veren çalışmalar içinde özellikle bazıları bu kapsamda paylaşılabilir. Bk. Yasemin Demircan, Tabrir Defterlerine Göre Boğąönü Adalar (XV ve XVII. Yüsynllar), Ankara Üniversitesi Sosyal Bilimler Enstitüsü Doktora Tezi, Ankara 1992; Ayhan Afşın Ünal, (XVI. Yüzyılda Cezâir-i Bahr-i Sefid Eyaleti’nde) Midilli Sancağı, Erciyes Üniversitesi Sosyal Bilimler Enstitüsü Doktora Tezi, Kayseri 2002; Filiz Yaşar Keskin, Bir Osmanl Adasinda Toplum ve Ekonomi (XVI. Yüryzldan XVIII. Yüzylla Sakıə), Hacettepe Üniversitesi Sosyal Bilimler Enstitüsü Doktora Tezi, Ankara 2013; Yasemin Demircan, Osmanl İdaresinde Limni Adasi, Ankara 2014; Mehmet Akif Erdoğru, Rodos'un Sosyal ve Ekonomik Taribi, İzmir 2018. 
durumdadır. Söz konusu çalışmalardan bir kısmı doğrudan Ege Adalarındaki Osmanlı kalelerine yönelik veriler ve açıklamalar içerse de ${ }^{5}$ kalelerde konuşlu askerlerin hangi mali koşullar altında görev yaptıkları hakkında değerlendirmeler ihtiva etmemektedir. Bu noktada mevacib türü defterlerden ilgi çekici verilere ulaşmak mümkündür.

Osmanlı maliye bürokrasisi, askerlere yapılan maaş ödemeleri konusunda üretilmiş bulunan ve mevacib defterleri adıyla anılan maaş defterlerini titizlikle tutmuştur. Bu defterler temelde askerlere yapılan ve günlük (yevm) üzerinden hesaplanan maaşların ödemesini yansıtmaktayd1. Kayıtlar, bir askerin tasarruf ettiği maaşın hukuki zeminini ${ }^{6}$ açıklamaya yönelik bilgiler içermektedir. Söz gelimi bazı gediklerin neden boş kaldığı, boş kalan gediklerin kimlere tevich edildiği ya da askerlerin içinden bazılarına neden zam yapıldığına ilişkin bilgilere bu kayıtlarda rastlanmaktadır. Makalede XVI. yüzyıl sonu ile XVII. yüzyıl başlarına ait mevacib defterlerin bazılarından yararlanılacaktır. ${ }^{7}$ Söz konusu tarihsel dönem Ege'deki Osmanlı egemenliğinin büyük ölçüde hedeflerine ulaştığ1, geleneksel rakiplerini (İtalyanlar, Şövalyeler vs.) kârlı Levant ticaretinin en önemli koridorundan (İstanbul - İskenderiye) uzaklaştırdığı bir sürece tesadüf eder. Henüz "hak arayışı" kavramının günümüzdeki romantik ve hukuki bağlamına oturmadığ1 ${ }^{8}$ modern öncesi dünyada, profesyonellikten stratejik hedeflere doğru uzanan geniş çaplı bir yaklaşımla hem ideal işleyiş hem de aksaklıklar beraber açıklanacaktır. Böylece Osmanlı Devleti'nin askerî bağlamda stratejik hedeflerine ulaşmak için seferber ettiği iş gücünün kapasitesi hakkında tespitlerde bulunulacağı gibi sıradan askerlerin kariyerleri için ortaya koyduğu girişimler hakkında da değerlendirmeler yapılacaktır.

XV. yüzyılın içinci yarısından itibaren Ege Adalarının kuzeyden güneye doğru Osmanlı Devleti'nin egemenliği altına girmiştir. Takip edilen temel statejik

5 Bunlardan Yasemin Demircan ve Ayhan Afşin Ünal'ın temel kaynak olarak XV ilâ XVII. yüzylllar arasına yayılan tahrir defterlerini seçtikleri anlaşılmaktadır. Söz konusu defterlerin bir kısmında kalelerdeki personel timar mutasarrıfi olarak gösterildiği için her iki tarihçinin de askerlerin gelirleri hakkında bir takım değerlendirmeler paylaştı̆̆ı görülür. Bk. Demircan, Boğaحönü Adalar, s. 91-104; Ünal, Midilli Adasi, s. 70-84, 129-130.

6 Maaş tasarruf hakkı gedik olarak tanımlanmaktadır. Dolayısıyla "gedik" tabiyile kaledeki bir kadroyu ifade etmek mümkündür. Kavramın hukuki ve iktisadi tanımı için ayrıca bk. Ahmet Akgündüz, "Gedik”, DIA (Türkiye Diyanet Vakfi İslam Ansiklopedisi), Cilt 13, İstanbul 1996, s. 541

7 Kayıt mantığının bir sonucu olarak mevacib defterleri kısa aralıklarla düzenleniyordu. Zira kalelerde görevli personelin bir kısmı dinamik bir şekilde sürekli olarak değişiyor ya da personelin maaşıyla ilgili gerekli düzenlemeleri sürekli olarak takip etmek gerekiyordu. Burada tarihsel olarak yalnızca karşılaştırma olanağı sunacak olan defterlerden yararlanılacaktır. Bunlar şu şekilde sıralanabilir. Bk. BOA (Cumhurbaşkanlığı Devlet Arşivleri Başkanlığı Osmanlı Aşivi).MAD.d. (Maliyeden Müdevver Defterler Fonu) nr. 4634, 5228, 5683, 6166, 7365, 7385.

8 Sadece felsefi anlamda temel insani ideallerden beslenen doğal hukuk ile tarih boyunca yazılı hukuk arasındaki farklar üzerine antropologlar tarafindan dikkate değer ölçüde fikir üretilmiştir. Günümüzde insan haklar olarak kavramsallaştırlan doğal hukuk, esasen 1776'da Amerikan Bağımsızlık Bildirisi ile 1789'da İnsan ve Yurttaş Hakları Bildirisi'nde ilk defa ifade bulmuştur. Daha kapsamlı tespitler için bk. Mehmet Şükrü Nar, "Jean-Jeacques Rousseau'nun Doğal Hukuk Anlayışı Üzerine Antropolojik Bir Değerlendirme”, Bilgi, 30 (2015 Yaz), s. 44-52. 
yaklaşım başlangıçta imparatorluk merkezini güven altına almayı hedefliyordu. Ege Deniz'inde seyreden başta ticari gemiler olmak üzere her türlü deni taşıtı belli bir koridorda hareket etmek zorundaydı. ${ }^{9}$ Hâkim rüzgarlar ve akıntılar denizcilerin önceden belirlenmiş olan rotalardan çıkmasına izin vermiyordu. $\mathrm{Bu}$ durum Anadolu'ya komşu Ege Adalarının, ticari faaliyetler bakımından önem kazanmasını sağlamıştı. Eldeki tarihî veriler, Osmanlı Devleti'nin geleneksel rakipleri olan İtalyan denizci devletleri Ege'nin kuzeyindeki adalardan çıkarılmasının ardından işte bu yoğun ticari faaliyetlerin gerçekleştirildiği limanlara ev sahipliği yapan adaların ve bölgedeki Türk egemenliğini güçlendirecek olan kalelerin aşamalı olarak fethedildiği görülür. ${ }^{10}$ Böylece, öncelikli olarak Anadolu'nun batı kıyıları boyunca, deniz güzergahının üzerindeki bir zincirin halkaları gibi kuzey - güney ekseninde dizilmiş adalara $^{11}$ asker konuşlandırlmıştı. Söz konusu kaleler, Akdeniz’in bu köşesinde Osmanlı egemenliğini destekliyor, ticari hacmin artabilmesi için ihtiyaç duyulan huzur ve güven ortamını olanaklı k1liyordu. Osmanlı Devleti'nin Levant ticareti üzerindeki denetimini güçlendiriyor ve Akdeniz'deki rakiplerine karşı donanmanın ihtiyaç duyduğu operasyonel alt yapıy1 (lojistik, güvenli liman vs.) sunuyordu. ${ }^{12}$ Dolayısıyla kaleler stratejik olarak çok yönlü hedeflere hizmet veriyordu. Kalelerin askerî kapasitesi üzerinde belirleyici etkilere sahip bileşenlerden belki de en önemlisi askerlerdi. Asker sayısında ise belirleyici faktörlerin başında finansman geliyordu. Söz gelimi XV. yüzyıl sonlarında Limni’deki Palukasrı Kalesi sadece 19 askerle müdafaa ediliyordu. Adada artan refaha bağlı olarak bu sayı takriben 30 yıl içinde 51'e yükselmişse ${ }^{13}$ de Limni'nin vergi gelirlerinden askerlerin maaşları için ayrılan pay değişmemiş, $\% 30$ civarında kalmıştır. ${ }^{14}$

9 John H. Pryor, Akdeniz'de Coğrafya, Teknoloji ve Savaș: Araplar, Bizanshlar, Batllhlar ve Türkler, (çev. F. Tayanç, T. Tayanç), İstanbul 2004, 98-105.

10 Ege Adalarının fetih sürecine yön veren stratejik yaklaşıma ilişkin kapsamlı bir değerlendirme için bk. Nalezen, Kalelerin Rolï, 165-173.

11 Bozcaada (بوزجه اطه / Tenedos), Limni (مدلله / Lلينوس / Lesvos /

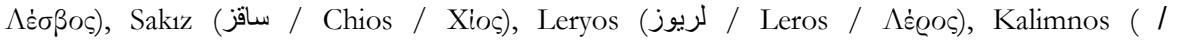

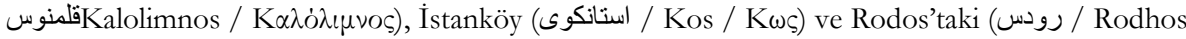
/ Póঠos) kalelerde asker bulunduruluyordu. Çalışmada yüzyıllarca Türk hâkimiyetinde kalmış bu adaların Osmanlı literatürüne yerleşmiş isimleri kullanılacaktır. Ege Adalarının taksimi ve tesmiyesi hususunda ayrıca bk. Haritalar ve Coğrafya Eserlerine Göre Ege Denizi ve Ege Adalar, (Ed. İdris Bostan, v.dğr.), Ankara 2003, s. 121-125. Adaların Osmanlı Türkçesindeki yazım biçimleri bu makalede kullanılan belgelerden alınmıştır.

12 Nalezen, Kalelerin Rolï, 163-173, 207-211.

13 BOA.TT.d. (Tapu Tahrir Defteri Fonu) nr. (numara) 25, s. 63-71; TT.d. nr. 75, s. 157-194.

14 Limni Adası'nın vergi geliri detaylı bir şekilde hesaplanmış durumdadır. Bk. Yasemin Demircan, Limni Adası, Ankara 2014, s. 285 vd. Söz konusu çalışmada Limni Adası'nda Türk egemenliğinin kurulması, adanın askerî ve idari olarak Osmanlı Devleti bünyesine alınması süreci kapsamlı bir şekilde ele alınmaktadır. Limni Adası'nda bulunan Palukasrı Kalesi'ne ilişkin açıklamalar için ayrica bk. Demircan, Limni Adasi, s. 60-64, 65-78, 296-299. 


\section{Personel Giderlerinin Finansmanı}

Ege'deki Osmanlı kalelerinin müdafaası temelde üç sınıf askere emanet edilmişti: topçular, hisar erleri ${ }^{15}$ ve azebler. ${ }^{16}$ Yerli kulu/kuloğlu/kul kardeşi $i^{17}$ bireylerin oluşturduğu bu askerlerin maaş ödemelerinin yükü esasen iki kaynağın üzerine yüklenmişti: tarımsal üretim ve ticaret gelirlerinden elde edilen vergiler. ${ }^{18}$ İstanbul'un Fethi'nden sonra ortaya çıkan stratejik yaklaşım önce Ege'nin kuzeyindeki adaların/kalelerin fethini gerektirmişti. Bu kapsamda Osmanlı kale teşkilatının taşındığ1 ve kurgulandığ1 ilk ada, Limni oldu. 1490'dan itibaren Limni'deki Palukasrı Kalesi personeline timar tevcih edilmiş, böylece maaş giderleri, Adalılar tarafindan üretilen katma değer üzerinden karşılanmıştı. ${ }^{19}$ Benzer bir yaklaşım Midilli'deki kaleler için de benimsenmişti. ${ }^{20}$ Bir sancak olarak ittihaz olunan Ada'nın idari sınırlarını kapsayan biri 1548, diğeri 1581'de olmak üzere iki sayım gerçekleştirilmişti. Söz konusu kayıtlarda ${ }^{21}$ Midilli'de bulunan kalelerde

15 Kale komutanı pozisyonunu işgal eden dizdarın ve onun yardımcısı olan kale kethüdasının emrinde gece-gündüz nöbet tutan, kalede ailesiyle birlikte ikâmet eden, tüfekli piyade sınıfi askerlere verilen genel addır. Bk. Ömer Lütfi Barkan, XV ve XVinci Asirlarda Osmanl İmparatorluğunda Ziraî Ekonominin Hukukî ve Malî Esaslar, I: Kanunlar, İstanbul 1943, s. 357; İlhan Şahin, "Timar Sistemi Hakkında Bir Risale", Tarib Dergisi, 32 (Mart 1979), s. 926; Sofyal Ali Çavus Kanunnamesi, (Haz. Mithat Sertoğlu), İstanbul 1992, s. 69.

16 Ok ve yay kullanan, XV. yüzylldan itibaren kalelerde görevlendirilen piyade sınıfı birliklerdi. Azebler, erken dönemlerden itibaren Osmanlı ordusunda yer almıştır. Azebler kalede ağalarının komutasında hareket ediyorlardi. Bk. Gyula Káldy-Nagy, "The First Centuries of the Ottoman Military Organization", Acta Orientalia Academiae Scientiarum Hungaricae, 31/2 (1977), s. 163; İdris Bostan, "Azeb”, DİA (Türkiye Diyanet Vakfi Islam Ansiklopedisi), Cilt 4, İstanbul 1991, s. 312. Azeblerin niteliği hakkında bk. Celâl-zâde Mustafa, Selim-nâme, (Haz. A. Uğur, M. Çuhadar), Ankara 1990, s. 130.

17 Kapıkulu ocağından ayrıldıktan sonra timar tasarruf eden sipahilerin, kapıkulu sipahilerinin, Divanıhümayun çavuşlarının ya da beylerbeyi divanında çavuşluk yapanların çocuklarını tanımlamak için "kul oğlu" tabirine başvurulduğu bilinmektedir. Bk. İsmail Hakkı Uzunçarşıll, Osmanlı Devleti Teşkilâtından Kapıkulu Ocaklar, I: Acemi Ocağı ve Yeniçeri Ocă̆̆, Ankara 1988, s. 33.

18 Örneğin Sakız Kalesi'nde görevli askerlerin gelirleri, Sakız Liman'ından elde edilen gelirlerle finanse ediliyordu. Bk. Sakız Kal'ası 'azeblerinden yüz doksan dokuz nefer kimesnelerin sene bin on yedi Receb ve Şẩban ve Ramazân aylarnda vấcib olan mevâciblerinin ... Cęîre-i Sakız İsklesi Gümrïgü ve tevâbi'hâ mukâta'ası kistından emîn-i mültęìm olan Abrabam veled-i David nâm Yebûdî tabvîlinden havâle idüb buyurdum... bk. BOA.MAD.d. nr. 4378, ferman 81.

19 BOA.TT.d. nr. 25, s. 63-71.

20 XVI. yüzyılda Midilli Adası'nda Osmanlı Devleti tarafindan takip edilen hukuki ve mali uygulamalar konusunda daha önce kapsamlı bir çalışma gerçekleştirilmiştir. Bk. Ayhan Afşin Ünal, (XVI. Yüzxyzlda Cezair-i Babr-i Sefid Eyaletinde) Midilli Sancağı, Erciyes Üniversitesi Sosyal Bilimler Enstitüsü, Doktora Tezi, Kayseri 2002. Ada'da bulunan Midilli ve Molivo kalelerine ilişkin söz konusu çalışmada yer alan açıklamalar için ayrıca bk. Ünal, Midilli Sancağ̆, s. 126-136.

21 Ünal, Midilli Sancă̆ı, s. 21-22. 1548 tarihli sayım sonucunda derlenen defterlerde Midilli Kalesi müstahfizlarının timarları için bk. BOA.TT.d. 261, s. 45-104; TT.d. nr. 264, s. 159-219. Midilli Kalesi azebleri için bk. BOA.TT.d. 264, s. 73-74; Molivo Kalesi müstahfızlarının timarları için bk. BOA.TT.d. 261, s. 105-116; TT.d. nr. 264, s. 221-229. 1581 tarihli sayım sonucunda derlenen defterde Midilli Kalesi müstahfızlarının timarları için bk. BOA.TT.d. nr. 594, s. 37-64. Molivo Kalesi müstahfızlarının timarları için bk. BOA.TT.d. nr. 594, s. 75-82. 
görevli askerlerin maaşlarının tarımsal üretimden elde edilen gelirle ödendiği sarih bir şekilde tespit edilebilmektedir. Bu finansman modeli Limni'de XVI. yüzyllın ortalarına kadar sürdürüldü. ${ }^{22} \mathrm{Bu}$ noktadan sonra Limni'deki Palukasrı Kalesi personelinin ulufeli hâle geldiği görülür. ${ }^{23}$ Ege'nin güneydoğusuna doğru diğer adalardaki, yani Sakız, Leryos, Kalimnos, İstanköy ve Rodos'taki kalelerde görev yapan neferat da ulufeli olarak istihdam edilmişti. Öte yandan XVII. yüzyıldaki kayıtlar Midillili müstahfizların timar mutasarrıfı olmaya devam ettiklerini göstermektedir. $^{24} \mathrm{Bu}$ durum imparatorluk sathını içine alacak ölçekteki genellemeler söz konusu olduğunda Ege'nin istisnai bir pozisyona sahip olduğunu düşündürebilir.

Mustafa Akdağ, geniş ölçekli bir yaklaşımla ulufeli statüdeki hisar erlerine XVI. yüzyıl ortalarından başlayarak timar tevcih edildiği yönünde değerlendirmeler paylaşmaktadır. ${ }^{25}$ Ancak yukarıda aktarılan tarihsel tecrübe Midilli örneğinde olduğu gibi Ege'de idari tasarrufun farklı uygulamalara başvurduğunu ortaya koymaktadır. Nitekim günümüzdeki bazı araştırmalarda timar sisteminin yüzyüze kaldığ1 dönüşüm zorunluluğunun bir ürünü olarak kalelerdeki ulufeli personel sayısının giderek arttırıldığına yönelik değerlendirmeler yapılmaktadır. ${ }^{26}$ Her ne olursa olsun kalelerde görev yapan askerlerin giderlerinin finansmanında kaynak çeşitliliğinden yana bir tavrın benimsendiği, adalardaki toprakların hukuki ve mali durumunu, üretim ilişkilerini köklü bir şekilde etkileyecek dönüşümlere mahal verilmediği anlaşılmaktadır. İmparatorluk, işleyen bir düzeni bozmak yerine esnek davranmayı daha pratik bulmuş gibidir.

\section{Askerin Maliyeti}

1548'e gelinirken Midilli Adası'nda görevli topçular timarlı statüye geçirildi. Tahrir defterinde bu hususa ilişkin yer verilen pasajda, düzenleme ile topçu bölük başılarına 2.000 akçelik, topçulara ise 1.600 akçelik dirlik tevcih edildiği belirtilmektedir. ${ }^{27}$ Böylece bir topçunun devlete günlük ortalama maliyetinin yeni düzenlemeyle birlikte 5 akçeye (bölük başllar 5,6 akçe, diğerleri 4,5 akçe) tesadüf ettiği hesaplanabilmektedir. Ege'deki kalelerde görev

22 BOA.TT.d. nr. 75, s. 157-194; TT.d. nr. 434, v. 84a-109a.

23 “... ziker olunan hâsslar bundan evvel cęîre-i mę̧û̀rede vâki olan Palukasn Kal'ası müstâhfı̨larmm timâr iken ...” bk. BOA.TT.d. 307, s. 1. Açık şekilde Limni'de müstahfız timarlarının kaldırıldığı, gelirlerinin de padişah hassına aktarıldığı belirtilmektedir. Yasemin Demircan, padişah gelirlerini arttırmaya dönük genel bir politikanın sonucu olarak böylesi bir uygulamanın hayata geçirilmiş olabileceği ihtimali üzerinde durmaktadır. Bk. Demircan, Limni Adası, 66.

24 I. Ahmed Dönemi'nde (1603-1617) Midilli'nin savunmasında görev alan personelin tasarruf ettikleri dirliklere ilişkin bir defter uluşamıştır. Bk. BOA.MAD.d. nr. 731, s. 25-40.

25 Mustafa Akdağ, Türkiye'nin İktisâdi ve İctimâ̂ Taribi, II (1453-1559), İstanbul 1979, s. 307 dipnot 2.

26 Ömer Gezer, Kale ve Nefer: Habsburg Sinrrnda Osmanl Askerî Gücünün Yeniden Örgütlenmesi (1699. 1715), Hacettepe Üniversitesi Sosyal Bilimler Enstitüsü, Ankara 2016, s. 75.

27 “...topçular ve topçu bölük basslarmm ulufeleri ref' olunub timar virilmesin emredüb bölük başı olanlarn ikişer bin ve topşularn bin altryüz akşe timâr tevcib olunmasin...” bk. BOA.TT.d. nr. 264, s. 8. 
yapan personelin maaşları genel anlamda değerlendirildiğinde bu tutarın ortalama bir değeri yansıttığını ifade etmek mümkündür. Yine de Midilli'deki topçular aynı dönemde (XVI. yüzyılın ortalarında), aynı işi Rodos'ta ya da İstanköy'de yapan meslektaşları kadar kazanmıyorlardı. Rodos Kalesi topçuları ortalama 6 akçe, Narince Kalesi'nde topçular ortalama yaklaşık 6,1 akçe, yine İstanköy'deki Pili Kalesi'nde ise 6,6 akçe kazanıyordu. ${ }^{28}$ XVII. yüzyılın hemen başında askerin sınıfına göre ortalama ne kadar kazandığını gösteren daha detaylı bir döküm aşağıda paylaşılmaktadır (Tablo I).

Tablo I: 1606'da Ege'deki Osmanlı kalelerinde görevli ulufeli 1 askerin günlük ortalama finansman maliyeti (akçe) ${ }^{29}$

\begin{tabular}{|c|c|c|c|c|c|c|c|}
\hline \multirow{3}{*}{ Ada } & \multirow{3}{*}{ Kale } & \multicolumn{6}{|c|}{ Birlik } \\
\hline & & \multirow{2}{*}{$\begin{array}{c}\text { Hisar } \\
\text { eri }\end{array}$} & \multirow[b]{2}{*}{ Topçu } & \multirow[b]{2}{*}{ Cebeci } & \multirow{2}{*}{$\begin{array}{c}\text { Geri } \\
\text { Hizmet } \\
\text { Bölükleri } \\
* *\end{array}$} & \multicolumn{2}{|c|}{ Azeb } \\
\hline & & & & & & Kara & Deniz \\
\hline \multirow{2}{*}{ Rodos } & Rodos* & 5,6 & 7,5 & 6,8 & 5,2 & 5,5 & 7,5 \\
\hline & Lindos & 5,4 & 6 & - & - & - & - \\
\hline \multirow{4}{*}{ İstanköy } & Narince & 6 & 6,4 & - & 6,5 & 5,4 & 8 \\
\hline & Andimahye & 5,5 & 6,4 & - & - & - & - \\
\hline & Pili & \multicolumn{2}{|c|}{6,1} & & - & - & - \\
\hline & Kefalos & 6,1 & 5,5 & - & - & - & - \\
\hline Leryos & Leryos & \multicolumn{2}{|c|}{7,6} & - & - & - & - \\
\hline Kalimnos & Kalimnos & \multicolumn{2}{|c|}{6} & - & - & - & - \\
\hline Sakız & Sakız & 5,3 & 6,1 & \multicolumn{2}{|c|}{5,6} & \multicolumn{2}{|c|}{5,2} \\
\hline \multirow{2}{*}{ Midilli } & Midilli & - & - & - & - & 4 & - \\
\hline & Molivo & - & - & - & - & - & 4 \\
\hline Limni & Palukasr1 & \multicolumn{2}{|c|}{3,5} & - & - & - & - \\
\hline Bozcaada & Bozcaada & \multicolumn{2}{|c|}{4,9} & - & - & - & - \\
\hline
\end{tabular}

28 BOA.TT.d. nr. 367, s. 211, 213. Söz konusu tutarlara asker sayısı ve toplam ödenen maaş miktarı arasında kurulan oranla ulaşılmıştır.

29 Tabloya kaynaklık eden veriler için bk. BOA.MAD.d. nr. 5683, s. 2-46, 55-73, 74-77, 78-80, 88103. Adalardaki kaleler, aynı savunma ağının parçası olduğu ve idari olarak Cezayir-i Bahr-i Sefid Eyaletinin bileşenlerini teşkil ettiği için bu kalelerde görev yapan askerlere ait verilere bazı defterlerde topluca ulaşılabilmektedir. 5683 numaralı defter de bu türden defterlerden biridir. Dolayısıyla karşılaştırmalı değerlendirmeler için oldukça uygun olduğunu savunmak mümkündür. 
* Kaleye bağlı dış tahkimatlar dâhil edilmiştir.

** Kalenin mehter takımı ile bakım - onarım işlerini yürüten, top mermisi imal eden personel (mehterân, neccârân, ahegengerân, senktraşân)

Tablo sarih bir şekilde hisar erlerinin ortalama 3,5 ila 6 akçe, topçuların 5,5 ila 7,5 akçe arasında değişen tutarlarda ortalama gelire sahip olduğunu ortaya koymaktadır. Kaleleri temele alan bir yaklaşımla bir askerin ortalama günlük maliyetinin adaların kendi içinde gelişmiş olan emek piyasasıyla ilgili olabilir. Muhtemelen Limni'de emek adaların kalanına göre daha ucuzdu. Bu sebeple asklerler daha azına razı olmak zorundalard. Her ne olursa olsun Ege'deki hisar erleri ve topçuların gelirleri kanunnamelerde idealize edilmiş olan koşullar altında imparatorluk vasatını hemen hemen yakalamış gibidir. Mısır'da hisar erleri 6, onlara komuta eden bölük başılar 7 akçe alıyordu. ${ }^{30}$

\section{Askerin Maişeti}

Üretebilir kapasitedeki her birey gibi asker de iş piyasasının bir parçasıydı. Dolayısıyla kalede babasından miras olarak aldığ ${ }^{31}$ ve "gedik" olarak tanımlanan pozisyona talip olması hâlinde vergi ödeyenler arasından ayrilmış oluyordu. Dolayısıyla kalenin kendisi adanın sınırlı emek piyasasının bir parçası olarak, önemli bir istihdam kaynağıydı. Peki bir asker gerçekte ne kadar kazanıyordu? Geçinebiliyor muydu? Bu soruya verilebilecek anlamlı cevaplara karşılaştırmalar yaparak ulaşmak mümkün olabilir. Böylesi bir karşılaştırma için iktisat tarihçileri yeterli miktarda datayı ortaya koymuş durumdadır. ${ }^{32} \mathrm{Bu}$ tespitleri paylaşmadan önce tarihsel kayıtlar üzerinden askerlerin geçim mücadelesini somut hâle getirebilecek birkaç örnek sunulabilir.

Hisar erlerinin görevlerinden elde ettikleri gelirle yetinemediklerini / yetinmedikleri gösteren çok sayıda kayda tesadüf etmek mümkündür. Ağriboz'da hisar erlerinden bazıları bağcllıkla meşguldü ve össr-i şire mükellefiydi. ${ }^{33}$ Müstahfızlık iyi bir gelir kaynağı olarak görülemezdi. Nitekim kimi kayitlarda bu askerlerin fukara oldukları vurgulanır. ${ }^{34} \mathrm{Bu}$ ifade onların otoriteye hitab ederken boyunların büktüklerini ya da kendilerini "aciz kullar" olarak göstermek için kullandıkları tevazu belirtme ihtiyacından ileri gelmemektedir. Temel bir gerekçesi vardı: Geçinemiyorlardı. Durumun sarih bir şekilde açıklandığ1 kayıtlar günümüze kadar ulaşmıştır: “... hâliyâa Cezâir Beğlerbeğisi olan emîrü'l-ümerâil'-kirâm ve'l-ikerâm Sâlih Paşa dâme ikbâlebu dergâh-ı mu'allâma 'ař gönderüb Rodos Kal'ası müstabfâżnın ve topçularmn

30 Barkan, Kanunlar, s. 357.

31 Kalelerde özellikle kul oğullarının istihdam edilmesine yönelik bir eğilim söz konusuydu. Bu husus hukuki bir zemine de oturtulmuştu. Bk. Barkan, Kanunlar, s. 357.

32 Süleyman Özmucur, Şevket Pamuk, "Real Wages and Standards of Living in the Ottoman Empire, 1489-1914", The Journal of Economic History, 62/2 (2002), s. 293-321.

33 Barkan, Kanunlar, s. Kanunlar, 341.

3412 Numaral Mühimme Defteri (978-979 / 1570-1572) <Özet-Transkripsiyon ve Indeks> (Haz. H. O. Yıldırım, V. Atik, M. Cebecioğlu vdğr.), Ankara 1996, 309-310. 
ekserî fukarâdan olmağın, ulûfelerin kılleti..."35 Ellerine geçen para, müreffeh bir yaşam sürmelerine imkân tanımıordu. Askerler kendileri ve aileleri için daha iyi hayat şartları elde edebilmek amacıyla ek iş yapmak zorundaydı.

Eldeki tarihsel kayıtlar ek iş konusunda Ege Adalarındaki kalelerde görev yapan askerlerin, imparatorluğun diğer sınırlarındaki ya da önemli ticaret yolları üzerinde ortaya çıkıp gelişen iskân merkezlerindeki meslektaşları kadar şanslı olmadığını düşündürmektedir. XVII. yüzyıl başında Rodos’un deryabeyi Mehmed, günlük 16 akçelik gelire sahip Hüseyin isimli bir bölükbaşının geçinmekte zorlandığını oldukça ikna edici bir anlatıma başvurarak arz etmişti. Kaledeki bu nitelikli ve uyumlu askerin günlük gelirinin 2 akçe daha arttırılmasını istiyordu. Mehmed Bey arzında, Bölükbaşı Hüseyin’in geçim sıkıntısını görev yaptı̆̆ı kalenin Rodos'ta olması üzerinden gerekçelendirmişti: “...lakin Rodos cez̧îre olmağla 'ulûfesi vech-i maîşetine vefâ itmeyüb... '’6 Deryabeyinin ifadelerinde Hasan'in geçim sıkıntısının kaynağ1 olarak Rodos değil, Rodos'un bir ada olması gösterilmektedir. Bu durumda adada hayatın imparatorluğun kalanına göre daha mı pahalı olduğu sorusuna cevap aramak anlamsız hâle gelmektedir. Asıl mesele adaların yeterli iş firsatı sunmaması olabilir. Sonuçta adaların ekonomik hacmi sınırlıydı. Dolayısıyla bir adada iş yapma, para kazanma olanakları da kısıtlıydı. Bölükbaşı Hüseyin, üstlerinin kendisinden memnuniyet duyduğu başarılı bir asker olmasına karşın belli ki bir adada görev yapmak zorunda olduğu için iş hayatının sunduğu firsatlardan yararlanamıyordu. Ancak aksi örnekler de vardır. 4 Ağustos 1553’e ait bir kayıtta, Midilli Kalesi azep birliğindeki ser-piyadegândan biri olan Hüseyin Divane isimli bir askerin uhdesinde 30.000 akçelik mukataa bulunduğu bildirilmektedir. ${ }^{37}$ Hüseyin Divane'nin durumunun ne denli istisnai olduğu hususu izahtan varestedir. Aslında askerin geçinmekte güçlük çekmesi fiyatlarla ilgiliydi.

Osmanlı Devleti narb olarak anılan bir araçla piyasaya müdahale ediyordu. Narh, esasen halkın iyi kalitede ürün ve hizmete yeterli miktarda ulaşabilmesi ve fiyat istikrarının sağlanabilmesi için tavan fiyat belirlemeye dayanıyordu. ${ }^{38}$ Araştırmacılar, Osmanlı kentlerinde narh üzerinden fiyatların gerçeğe oldukça yakın bir seyrinin takip edilebileceği kanaatindedir. ${ }^{39}$ Dolayısılla narh üzerinden bir anlamda tüketici fiyatlar endeksini okumak mümkündür. ${ }^{40}$ Ancak daha da önemlisi ekonomi tarihçileri, iş piyasasının dönemsel olarak seyrini takip etmek için İstanbul başta olmak üzere imparatorluğun gelişmiş kentlerinde yürütülen imar projelerinde

35 BOA.MAD.d. nr. 233, s. 83, hük. 1.

36 BOA.MAD.d. nr. 5683, v.2/2.

37 BOA.MAD.d. nr. 619, s. 60.

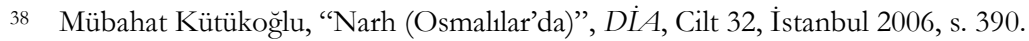

39 Değerlendirmelerini, Mehmet Genç’in Osmanlı ekonomisinin işleyişine ilişkin önerdiği prensipler üzerine kurgulayan Şevket Pamuk, Osmanlı Devleti'nin narh uygulaması üzerinden piyasanın dengesini sarsıcı müdahalelerde bulunmadığını ortaya koymaktadır. Bk. Şevket Pamuk, A Monetary History of the Ottoman Empire, Cambridge 2003, s. 14-15. Mehmet Genç'in değerlendirmeleri için ayrica bk. Mehmet Genç, Osmanli İmparatorluğunda Devlet ve Ekonomi, İstanbul 2010, s. 61-68.

40 Özmucur, Pamuk, "Real Wages”, s. 296-298. 
istihdam edilen işçilerin maliyetleri üzerinden hesaplamalara girişmiştir. ${ }^{41}$ Öyleyse elimizde askerlerin gelirlerine (mevacib), geçim maliyetine (narh), işgücü piyasasına ilişkin ayrıntılı veriler/hesaplamalar mevcuttur.

Osmanlı Devleti'nin askerî anlamda Akdeniz ölçekli politikalarında bir mızrak ucu gibi işlev gören, donanma operasyonlarına dayanaklık eden bölgedeki en önemli askerî üs Rodos Kalesi'ydi. 1604 yılında Kale'de görevli hisar erlerinin ortalama gelirinin 5,6 akçe, topçularınkinin ise 7,5 akçe olduğu hususu yukarıda paylaşılmıştı (Tablo I). Tam da bu dönemde (1600-1609) niteliksiz bir inşaat işçisi günde ortalama 13,9 akçe (4 gr gümüş), bir usta ise 22,5 akçe (6,5 gr gümüş) kazanıyordu. Osmanlı İmparatorluğu'nun Akdeniz'deki belki de en önemli donanma üslerinden birinin savunmasını üstlenmiş askerler, niteliksiz bir inşaat işçisi kadar kazanamıyordu. Burada, düzenli gelire ve mesleğini miras olarak birakmak gibi temel hukuki ayrıcalık ve güvencelere sahip bir grup (askerler) ile düzenli olarak istihdam edilemeyen ve yll içinde sadece inşaat mevsiminde çalışabilen bir grup (işçiler) karşılaştırılıyormuş gibi görünebilir. Ancak amaç matematiksel bir kesinlikte askerlerin geçinemediklerini ortaya koymak değildir. Tarihsel bulgular böylesi bir çabaya girişmeyi gerektirmeyecek kadar sarihtir. Amaç, emek piyasasından çekilen bireylerin ne kadarına razı olduklarını ortaya koymaktır. Her ne olursa olsun askerler, ücreti piyasa tarafından belirlenen nitelikli/niteliksiz iş erbabı kadar kazanamıorlardı. Dahası ödemelerde daima aksaklıklar yaşanma ihtimali vardı. Bunun da ötesinde askerlik mesleğinin doğal riskleri söz konusuydu.

Ücretlerin fiyatlar karşısında erimesi ise maaşlı kale personeli için bir başka meseleyi teşkil ediyordu. Söz gelimi Ege'nin doğu tarafında en son fethedilen ve imparatorluğun askerî ve idari kurumlarının en son taşındığı ada Sakız'dı. Sakız Kalesi'nde işleyiş ve organizasyon bakımından ideale yakın bir yapı tesis edilmişti. Dolayısıyla Sakız Kalesi'nde görevli askerlerin uzun süreli maaşlarında yaşanan değişimin takip edilmesi, enflasyon karşısında askerin alım gücünün seyri hakkında da fikir verebilir. Tablo II, Sakız Kalesi’nde görevli hisar erlerinin ortalama günlük gelirinin y1llar içindeki seyrini göstermektedir.

Tablo II: Sakız Kalesi'nde görevli hisar erlerinin ortalama günlük geliri (1579 - 1642) ${ }^{42}$

\begin{tabular}{||l|c|c||}
\hline Tarih & $\begin{array}{c}\text { Ortalama } \\
\text { gelir (akçe) }\end{array}$ & Değişim (\%) \\
\hline 1579 & 5,4 & - \\
\hline 1606 & 5,3 & $-3,3$ \\
\hline 1631 & 5,4 & 1,9 \\
\hline
\end{tabular}

41 Özmucur, Pamuk, "Real Wages”, s. 304-307.

42 Verilerin derlendiği kaynaklar için bk. BOA.MAD.d. nr. 5228, s. 81-86; MAD.d. nr. 5683, s. 8894; $M A D$. d. nr. 7365, s. 112-119; MAD.d. nr. 4634, s. 79-84. 


\begin{tabular}{||l|l|l||}
\hline $1636 / 1637$ & 5,1 & $-4,1$ \\
\hline 1642 & 5,4 & 4,2 \\
\hline
\end{tabular}

Tablo II'de gösterilen 63 yıllık süreç, Sakız Adası'nda enflasyonun ortadan kaldırıldığı intibaını uyandırabilir. Bununla birlikte narh kayıtlarına dayalı tüketici fiyatlar endeksi hesaplamalarına bakıldığında aksi bir manzarayla karşılaşılmaktadır. Söz konusu dönemi içine alan süreçte dalgalanmalar yaşanmakla birlikte temel tüketim maddelerinden oluşturulan fiyat sepetinde \%119 düzeyinde bir artışın meydana geldiği görülmektedir. ${ }^{43}$ Askerin ücreti ile Yeniçeri Ocağının nizamı arasındaki bağı kantitatif olarak ilk defa ortaya koyan tarihçilerin başına Mustafa Akdağ gelmektedir. Onun tespitleri enflasyon karşısında eriyen asker maaşlarının durumunu anlamak için oldukça yol göstericidir. Maaşının alım gücünü referans alan bir hesaplamayla XVI. yüzyıl sonlarında bir yeniçerinin en az 20 akçelik ulufe tasaruf etmesi gerekiyordu. Oysa yüzyılın başında günlük ortalama 4 akçe kazanan bir yeniçeri, yüzyılın sonlarına doğru en fazla ortalama 7 akçe kazanabiliyordu. ${ }^{44}$ Benzer şekilde veriler, Sakız'da görev yapan askerlerin de giderek fakirleştiğini ortaya koymaktadır. Öyle ki XVI. yüzyılın sonlarına gelindiğinde Sakız Kalesi’nde görev yapacak yarar adem bulmak imkânsız hâle gelmişti:

"Kal'a-y Mezbûrenin kâdîmden altıyüz nefer re'îs ve 'az̧ebleri olub ulûfeleri dörder akçe olmağla mahlûl düsen gedikleri kimesne kabûl itmemekle küllì ba'de dört yüz nefer olub ve bir akçe terakeki olmast 'arz itmeğin buyrulmustur."45

Sakız Kalesi azeb birliğinin mevcudu bir türlü doldurulamayan gedikler sebebiyle $1 / 3$ oranında azalmıştı. Karar alıcılar bunun sebebi olarak askerlerin geçim sıkıntısı çekmesi olduğunu anlamışlar ve sorunun çözüme kavuşturulabilmesi için maaş zammı yapılması ihtiyacını ortaya koymuşlardı. Söz konusu düzenleme Cigalazâde Sinan Paşa'nın kaptanpaşalık devresinde (1591-1595)46 bizzat Sinan Paşa'nın girişimleriyle gerçekleştirilmişti. Hayatı ve kariyeri hakkında bilinenler ${ }^{47}$ Sinan Paşa'nın Akdeniz’i etkisi altına alan enflasyon baskısı hakkında yeterli bilgi ve görgüye sahip olduğunu düşündürmeye yetecek keyfiyettedir. Sinan Paşa sadece Sakız değil, Narince azebleriyle ilgili de maaş iyileştirmesi yapılmasını istemişti. ${ }^{48}$ Asker başına sadece 1 akçelik inayet buyrulması bile hazinenin üzerinde yıllık binlerce

43 Özmucur, Pamuk, "Real Wages”, s. 301.

44 Mustafa Akdağ, "Yeniçeri Ocak Nizamının Bozuluşu", Ankara Üniversitesi Dil ve Tarib-Coğrafya Fakültesi Dergisi, 5/3 (1947), s. 298. Akdağ'ın verilerinden de beselenen Ömer Gezer, XVII. yüzyılın ikinci yarısında Fransız ve Habsburg ordularındaki durumu da ortaya koyarak imparatorluk ile rakipleri arasındaki istihdam politikasının benzerlikleri üzerinde durmaktadır. Bk. Gezer, Habsburg Sinirnda, s. 293 vd.

45 BOA.MAD.d. nr. 6166, s. 72.

46 Kâtib Çelebi, Tuhfetü'l-Kibâr fî Esfâri'l-Bihâr, (Haz. İdris Bostan), Ankara 2008, s. 139.

47 Mahmut H. Şakiroğlu, "Cigalazâde Sinan Paşa”, DİA, Cilt 7, İstanbul 1993, s. 525-526.

48 BOA.MAD.d. nr. 6166, s. 72. 
akçelik ek yük oluşturmuş olmalıdır. Maliyetlerin büyüklüğüne rağmen maaş, bir yönüyle ordunun kurumsal bünyesi içinde çözülmesi gereken stratejik meselelerden biri olagelmiştir.

\section{Mevacib ve Savaşma İştiyakı: Profesyonelleşme}

Savaş, şiddetin en organize ve yaygı̀n hâlidir. Ünlü Prusyalı askerî teorisyen Carl von Clausewitz savaş tanımının merkezine düelloyu yerleştirir. Adeta savaşın şiddet yönünü açık saçık hâle getirmek istemiş gibidir. ${ }^{49}$ Savaşı, kaçınılmaz olarak iki kişiden birinin yenilgiyle yüzleşeceği, şiddet uygulamakta daha mahir ve belki de daha şanslı tarafın kazanacağı bir mücadeleyle özdeşleştirir. Bir askeri böylesine ölümcül bir şiddetin orta yerinde mesleğini icra etmeye teşvik eden unsurlar tarihin her döneminde farklı kaynaklardan beslenmiştir. Şurası bir gerçektir ki karar alıcılar, "vatan" ve "ulus" gibi kavramların henüz ortaya çıkmadı̆̆ı Erken Modern Dönem'de, neferi motive etme kaygısından çok itaat altına alma arzusuyla hareket etmişti. ${ }^{50}$ Zira kopmasının isyan anlamına geleceği emir-komuta zincirini var eden disiplin, aslında itaat etme davranışının sistematik hâlidir. ${ }^{51}$ Osmanlı Devleti'nin modernleşme tecrübesi, profesyonelleşmenin bir ordunun erleri üzerindeki itaat üretimi kapasitesini belirleyen etmenlerden biri olduğunu göstermektedir. Özetle sadece neferlerini/savaşçılarını itaat altına almış, disiplin içinde hareket eden bir ordu; ölme ve öldürmeyi profesyonelce gerçekleştirebilirdi.

Büyük hayal kırıklarının ve askerî travmaların sarstığı psikolojik ortamda Osmanlı ordusunun hizmetine giren Comte de Bonneval (Ahmed Paşa), daha sonra kendisinin de "humbaracı" olarak anılmasını sağlayacak olan Humbaracı Ocağını teşkilatlandırırken öncelikle maaş meselesini ele almıştı. ${ }^{52}$ Belli ki Humbaracı Ahmed Paşa, emrindeki askerlerin düzenli maaş almasını modernizasyon yolunda atılan adımlardan biri olarak görüyordu. Nitekim sonraki süreçte de birliklerin profesyonel karakterini güçlendirmek için düzenli maaş ödemesinin hukuki zeminini güçlendirmeye yönelik uygulamalar hayata geçirilmişti. ${ }^{53}$ Özetle Erken Modern Dönem'in sonlarında ve Modern Çă̆'ın başlarında düzenli ve merkezî birlikleriyle savaş meydanlarında büyük zaferler kazanmış olan Osmanlı'da devlet aklı, askerî disiplin - profesyonelleşme - düzenli gelir üçgeni arasındaki bağı kurmuş bulunuyordu. Osmanlı Devleti'nin organizasyon becerisi belki de en çok askerî harcamaların finansmanı için ortaya konulan çabada kendini gösteriyordu. Nitekim bu organizasyonda husule gelen aksaklıklar, askerleri imparatorluk merkezini içine alacak büyük huzursuzluğun

49 Carl von Clausevitz, On War, (çev. Michael Howard, Peter Paret), Oxford 2007, s. 13.

50 Ulrich Bröckling, Disiplin: Askeri İtaat Üretiminin Sosyolojisi ve Taribi, (çev. Veysel Atayman), İstanbul 2008, s. 23.

51 Richard Sennett, Otorite, (çev. Kamil Durand), İstanbul 2014, s. 106.

52 Abdülkadir Özcan, "Humbaracı Ahmed Paşa”, DİA, Cilt 18, İstanbul 1998, s. 351-352.

53 Hamiyet Sezer Feyzioğlu, "III. Selim Dönemi’nde Humbara Ocağı’nda Yapılan Düzenlemeler", Tarih Arastırmalar Dergisi, 35/60 (2016), s. 145 vd. 
öznesi hâline getirebiliyordu. ${ }^{54}$ Ege'deki kalelerde ise askerlerin oluşturduğu toplumsal grup; huzuru, güvenliği ve genel anlamda devlet otoritesini tehlikeye düşürecek nitelikte bir hareketi tetikleyebilecek potansiyeli barındırmıyordu. Adalardaki askerler yaşadıklarını inayet ve sadaka beklentisi içinde dile getiren mağdurlardan daha fazlası değildi. 1627 Baharı'nda aylardır ödeme alamayan Palukasrı personeli -kayıtlara yansıdığı kadarıyla- sadece durumlarını izah eden bir arzda bulunabilmişti:

"[Kal'a]-yı Mezbûre neferâtı 'arz-ı hâl idüb elli tokuz nefer kal'ann hifz. u hirâsetinde olub yevmiyyeleri iki yüz altmıs sekiz akçe ve üc aylık mukarrerleri yirmi üc bin yediyüz on sekiz akģe olub lâkin haylî zemândır ulîfelerimiz dâhil olmayub bâlâ virilmek bâbında [emr-i şerîfe] ricâ eylemeğin üslûb-ı sâbık üzere mevcûdlarna ulûfe virilmek içün [emr-i şerîfim] virilmek fermân olmusdur. Imdi sen ki sancak beğisin mezkêurlarm [mustehak] [olduklar1] beher üc aym vâki' olan mevâcibleri bi kusûr [virilüb] [emr-i şerîfe] muhâlif olunmayub viresiz söyle bilesiz... Tabrîren Gurre-i Şa'bân sene 1036"s5

Nisan 1627 tarihli bu kayda göre Palukasrı garnizonunun günlük toplam finansman maliyeti 268 akçeydi. 59 asker için yapılması gereken üç aylık 23.718 akçe tutarındaki ulufe ödemesi bir türlü gerçekleştirilememiş, bu konuyla ilgili derya beyi görevlendirilmişti. Benzer şekilde 1628-1630 yıllarında Narince Kalesi'nin varoşunda görevli azeblerin ağası da maaşını alamamıştı: “...bu kullar Cę̧îre-i İstanköy varoşu ă̆ası olub alınacak bakâyâ ulûfelerimiz, var idi. Sa'âdetlü sultana 'arz-ı hâl itdüğ̈umüzde salyâne virdiğiniz. lâkin... "'56 Bu örnekler askerlerin aylarca ödeme almay1 beklemek zorunda kaldıklanını göstermektedir. Dahası bazı durumlarda defterlerde kaydedilen tutarları bile alamadıkları anlaşılmaktadır. Narince Kalesi azeb birliği askerleri maaşlarını nakit alamamaktan şikâyetçiydi:

"Vezîr Kapudan Sinan Paşa (Cigalazâde) kullar 'arz gönderüb İstanköy

Cezîiresi'nde Narince Kal'ası 'az̧eblerinin ulûfeleri yevmî dörder akçe olub anı dahi nükûd almayub ba'zı esbâb behâsından ancak ikişer vâsıl olmakıla

54 Osmanlı ordusunun maaş yani ulufe alan personelin kahir ekseriyetini kapıkulları teşkil ediyordu. Özellikle yeniçeriler savaş meydanlarında gösterdikleri yararlıklar kadar gerçekleștirdikleri ayaklanmalarla da tarihteki yerini almış bir birlikti. Yeniçeri isyanları hakkında toplu bir değerlendirme için bk. Kemal Beydilli, "Yeniçeri", DİA, Cilt 43, İstanbul 2013, s. 454. Fiyat artısları ve akçede meydana gelen değer kaybı ile toplumsal huzursuzluk arasındaki bağa işaret eden bir değerlendirme için bk. Fernand Braudel, Frank Spooner, "Prices in Europe from 1450 to 1750", The Cambridge Econonic History, Cilt IV (Ed. E. E. Rich, C. H. Wilson), Cambridge 1967, s. 380.

55 BOA.MAD.d. nr. 12760, s. 52. Defterde haşere tahribatı olduğu için bazı ifadeler okunamamaktadır. Tamamı ya da birden fazla harfi seçilemediği için kontekste bağlı olarak tahminen yazılan kelimeler köşeli parantez içinde gösterilmiştir.

$56 \quad$ BOA.MAD.d. nr. 7365 , s. 104 


\section{geçinmeğe iketidârlar olmamağın sâir kal'alar 'az̧ebleri gibi ulûfeleri beş akçe olmak ricâsına 'ilâm ider.' 57}

Tatbikat, ödemelerde yaşanan aksaklıkların profesyonelleşme önündeki engellerden sadece birini teşkil ettiğini göstermektedir. Bir diğer mesele ise hukuki güvenceydi. Askerin kale kadrosu içindeki varlığını güvence altına alabilecek her türlü hukuki kayda rağmen bir süre için görev yerinden uzaklaşması bile gediğini yitirmesine yol açabilirdi. 1636'da Rodos'tan Hacca giden ve yolculuğu öncesinde silah arkdaşları ile komutanlarını bilgilendiren Mehmed isimli bir topçu, Mekke'den döndüğünde gediğinin Siyavuş isimli bir asker tarafından ele geçirildiğini görmüştü. ${ }^{58} \mathrm{Bu}$ türden örneklerin varlığına rağmen askerler açısından gediklerin sağladığı hukuki güvenceden çok elde ettikleri gelirin düzeyi sorun teşkil ediyordu. Bu hususu günümüz maaşlılarının sorunlarından birini açıklamak için başvurduğu bir deyimle sunmak mümkündür: Eşit işe eşit ücret.

Özellikle henüz formel eğitimin kurumsal anlamda ortaya çıkmadığ1 modern öncesi dünyada, belki de yeteneklerin, ahlaki hasletlerin, gözüpeklik gibi karakter özelliklerinin en etkili şekilde takdir edildiği alanlardan biri askerlikti. Mahir askerleri teşvik etmenin en doğrudan yolu ulufe terakkisi yani maaş zammıdı. Bazen çatışmalar sırasında sıradan bir asker bile mücadelenin seyrini değiştirecek bir kader anında baş rolü üstlenebiliyordu. Rodos Kalesi Topçubaşısı Ali bu türden askerlerden biriydi. 1570’te Lefkoşe Kuşatması sırasında gerçekleştirdiği atışlarla sadece surlarda bir gedik açılmasını sağlamamış, komuta ettiği batarya bir düşman kolomborne topunu susturmayı başarmıştı. Bu muvaffakiyeti karşısında ulufesine 2 akçelik bir zam yapılmış ve günlük geliri 9 akçeye çıkarılmıştı. ${ }^{59}$ Dolayısıyla bir Osmanlı kalesinde bölük başılardan başlayarak dizdara kadar olan hiyerarşide bir askerin neden diğerine komuta ettiğini açıklamak ideal koşullarda güç değildir. Yine de bazı askerler anlaşılması güç bir şekilde daha fazla kazanıyordu. Öyle ki askerlerin içinden birileri ufak bir birlikle savunulan kalelerin kethüdaları hatta dizdarları kadar gelir elde ediyordu. İlginç bir şekilde bunlar zabitan kadrosunda bile yer almıordu. Söz konusu neferlerin silah arkadaşlarına göre daha fazla kazanmasının askerlik mesleğinin doğasıyla hiçbir ilgisi yoktu. Belgelerin diliyle ifade etmek gerekirse kale personelinden bazıları bir tarîkle getirisi yüksek bir gedik elde etmeyi başarmış görünüyordu. Askerlerden bazılarının geçim sıkıntısı çektiği koşullar altında bu adaletsizlik hem savaşma iştiyakını olumsuz etkileyebilecek hem de istihdam sürecini tıkayabilecek bir mahiyet kazanabilirdi. İstanköy'de de böyle oldu.

57 BOA.MAD.d. nr. 6166, s. 72. Kale personelinin techizat giderleri devlet tarafindan karşılanıyordu. Bu kapsamda askerlere çuba bahası da ödeniyordu. Bk. Şahin, İ. (1979), 926; Sofyalı Ali Çavuş Kanunnamesi (1992), 69.

58 BOA.MAD.d. nr. 7186, s. 23/1.

59 BOA.A.DVNSMHM.d. (Bâb-1 Asafî Mühimme Defterleri Fonu) nr. 8, s. 89, hük. (hüküm numaras1) 984. 
1606'da Narince Kalesi hisar erlerinden 2. bölükte görev yapan Yusuf Mehmed, 13 akçelik bir gedik tasarruf ediyordu. Aynı bölükte Yusufun silah arkadaşı Piyale b. Abdullah 10 akçelik bir gediğe malikti. Bu iki askerin günlük gelirini istisnai hâle getiren birkaç husus vardı. Öncelikle bölük komutasının teslim edildiği Bölükbaşı Mustafa Bali’nin kendisi sadece 7 akçe ulufe alıyordu. ${ }^{60}$ Bir askerin bölük başılık pozisyonuna getirilmesindeki temel ölçütlerden birinin liyakat olduğunu var saymak için elde yeterli tarihsel kayıt vardır. ${ }^{61}$ Maaş, askerin yeteneklerini takdir etmenin bir yolu olarak görülecekse eğer Yusuf ve Piyale’yi komutanları Mustafa'dan daha evla kilan bir yetenekleri olmaliydı. Ancak defterde bu hususta herhangi bir açıklama yoktur. Daha istisnai olanı kaledeki 14 bölükten hiçbirin komutanı, hatta dizdarın kendisi bile Yusuf kadar kazanmiyordu. ${ }^{62}$ Yusuf, kağıt üzerinde, aldığ1 maaşa bakılacak olursa kaledeki bölük başıların tamamından daha iyi bir askerdi. Ancak bir bölüğe komuta edebilecek kadar liyakat sahibi değildi. Çünkü hiçbir bölüğün komutası Yusufa emanet edilmemişti.

Kayıtlar daha dikkatli tarandı̆̆ında Yusuf ve Piyale'nin yalnız olmadığı görülür. Kalede bu tarihte günlük 8 akçe ve üzeri kazanan 9 asker vardı. Bunlardan hiçbirinin neden daha fazla kazandığını ifade eden herhangi bir not, deftere düşülmemiştir. Oysa iş yükü ya da sorumluluk tanımı sebebiyle daha fazla geliri tasarruf etmesi uygun görülen askerlerin isimlerine ilave edilen önemli açıklamalar bulunuyordu. Söz gelimi kalenin zindan sorumlusu olan Ömer Hasan'in neden ortalamanın (6 akçe) üzerinde ulufeye (7 akçe) mutasarrıf olduğu hasseten belirtilmişti. ${ }^{63}$ Söz konusu kişiler bir hisar erinin ortalama gelirinden $\% 30$ ila \%113 arasında değişen oranlarda daha fazla gelir elde ediyordu. Dahası bu fazladan ulufe mutasarrıfi askerler hesaplama dişı tutulursa bir hisar erinin ortalama geliri 6 akçeden 5,7 akçeye düşüyordu. Ortada bir çeşit usulsüzlük var gibi görünüyordu.

Ulufe ve gedik usulsüzlüğü Osmanlı ordusunun kronik sorunlarından biriydi. Örneğin 1585'te Arnavutluk hududunda gerçekleştirilen tahkikat sonucunda kalelerin boş kaldığ1 tespit edilmişti. Oysa kağıt üzerinde bu kalelerin tamamında askerler bulunuyor, bu askerler de gediklerinin karşıllı̆ında düzenli olarak ulufelerini alıyorlardı. Soruşturma sırasında "sözde" müstahfızlara ulaşılmış, bu kişilerin durumdan habersizce yaşadıkları anlaşılmıştı. Arnavutluk taşrasının nüfuzlu sipahilerinden bazıları adamlarını müstahfız yazdırıp, onlardan habersiz bir şekilde ulufelerini tasarruf etmişlerdi. ${ }^{64}$ Arnavutluk, belki de, imparatorluk hudut boylarının en kritik hattını teşkil ediyordu. Burası, Osmanlı Devleti'nin

\footnotetext{
${ }^{60}$ BOA.MAD.d. nr. 5683, s. 55.

61 Sadece bir örnek olarak Sakız Kalesi’nde görevli Mehmed isimli bir hisar erine ilişkin gerçekleştirilen yazışmalar paylaşılabilir: "Mehmed gelip yevmî beş akşe ile Sakız Kalesi müstahfı̨larnndan olup kadimi emekdâr olduğun bildirip bölük başıllk ricâ etmeğin düsenden bölük başılı verilmek buyuruldu." Bk. BOA.A.DVNSMHM.d. nr. 45, s. 364, hük. 4394.

62 BOA.MAD.d. nr. 5683, s. 55-59.

63 “Ömer [b.] Hasan, Zindânî 7 [akçe]”. Bk. BOA.MAD.d. nr. 5683, s. 57.

64 BOA.A.DVNSMHM.d. nr. 33, s. 253, hük. 517.
} 
Akdeniz'deki geleneksel rakibi Venedik Cumhuriyeti'nin sürekli olarak tehdidi altındaki bir sahaydı. Güçlü kalelerle müdafaası stratejik bir zorunluluk arz ediyordu. Böylesi bir sahada bu kadar kapsamlı bir usulsüzlüğün söz konusu olması, merkezin taşra üzerindeki denetleme araçlarının yetersizliğiyle ilgiliydi ve Ege'de de aynı sorunların yaşanmaması için hiçbir gerekçe yoktu.

İstanköy'de bir grup askerin, kalede çalışma ahengini, silah arkadaşlığı ruhunu sarsacak şekilde hakkettiğinden daha fazlasını kazanması bir süre sonra fark edildi. Ortaya çıkan adaletsizliğin üstesinden gelebilmek için 1636'da istisnai bir uygulama hayata geçirildi:

'Kal'a-y Narince ve tevabihâ kulâ' neferlerinden bazllar 'ulufelerin bir yerden terakeki ile ziyâde idüb fukaraya bes ve altı akçe yevmiye ile kalub ve mevacibleri dahi vâcib olmakla ekserî yerlerinde olub Vezîr Kapudan Paşa muhâfazầ ile mubit-i mezkûra uğrayub ziker olunan kal'alarn neferâtı yokladukda ekseri nâ-mevcûd bulunmağla ve kal'alar kemâkân hrfz. u hiraset olunmak babinda yevmiyeleri bir tarikle yediserden ziyâde bulunanlarun mevâciblerinden fürubde olunub evvelki garîb ve yarar kişiler beş akçe ile kalmısdır. Anlarn 'ulufelerine zamm olunub ... bazllarmm ziyadesi bazlarna zam olunub bunlarn ulufeleri ale's-seviye yedişer akçe olmak üzere Kapudan Paşanin minval-ı meşrûh tertîb ve münâsib gördü̈üu üzere emr-i şerîfe ... 'r5

Ortaya konulan çözüm, askerin dünyasını iyi kavramış bir asker/devlet adamının anlayışını yansıtır niteliktedir. Eldeki kaydın yalnız makamını açıklamakla yetindiği kaptanpaşanın Kemankeş Kara Mustafa Paşa olduğu anlaşılmaktadır. ${ }^{66}$ Kariyeri hakkında bilinenler, I. İbrahim ve IV. Murad dönemlerinde kritik görevler üstlenmiş bu devlet adamının, işleyiş ve idari konularda bilgili; cesareti, dürüstlüğü ve aklı takdir edebilecek hasletlere sahip biri olduğunu düşündürmektedir. Dahası reformist tarafı güçlü olan adil bir devlet adamıdı. ${ }^{67}$ Özetle Narince Kalesi’ndeki düzenlemeyi gerçekleştirebilmek için bir idarecinin sahip olması gereken hasletleri bünyesinde barındırıyordu. Düzenlemenin gerçekleştirildiği tarih esasen Mustafa Paşa'nın kaptanpaşalık pozisyonuna geldiği döneme tesadüf eder. Paşa belli ki idari yetki alanında yaşanan aksaklıkları gözlemleyebilmek maksadıyla kapsamlı bir teftiş gerçekleştirmişti: "V equîr Kapudan Paşa muhâfazâ ile muhit-i meqkûra uğrayub zịkr olunan kal'alarn neferâtı yokladukda..." Narince'de öncelikle gelir adaletine ihtiyaç vardı. Ancak yukarıda da ifade edildiği üzere devletin, askerlerin yaşadı̆̆ı ekonomik sıkıntıları çözüme kavuşturacak mali gücü mevcut değildi. Dolayısıyla askerlere savaş iştiyakını kazandırmak için adaleti sağlamak en etkili yoldu. Mustafa Paşa,

65 BOA.MAD.d. nr. 7385, s. 74.

66 Kemankeş Kara Mustafa Paşa, 1635 - 1638 y1lları arasında görev yapmıştı. Bk. Kâtib Çelebi, Tubfetü'l-Kibâr, s. 140; İsmail Hâmi Danişmend, Osmanl Devlet Erkâm, İstanbul 1971, s. 189-190.

67 Faik Reşit Unat, "Sadrazam Kemankeş Kara Mustafa Paşa Lâyihası", Tarih Vesikalar, 6/1 (Nisan 1642), s. 444. 
hiçbir ek kaynağa ihtiyaç duymadan kaledeki askerlerin ortalama gelirini arttırmay1 başard. Narince'de hisar erlerinin ortalama ulufesi 6 akçeden (gerçekte 5,7 akçe) 7 akçeye ç1kmışt1. ${ }^{68}$

Aslında sorunun kaynaklarından birisi de usulsüzlüğe en başında aracılık ve müsaade edenler yani otoritenin arasına yuvalanıp görevini kötüye kullanan idarecilerdi. Ancak bu idarecilerin cezalandırılması, taşrada kendine has bir dengeye kavuşmuş ilişkilere sert şekilde müdahale etmek anlamina gelebilirdi. Bu sebeple olsa gerek sorumluların cezalandırılmasına yönelik en azından bu belgede herhangi bir hususa işaret edilmemiştir.

\section{Sonuç}

Yaşanların kayıtlara yansıyan tarafları yeri geldiğinde ölmek ve öldürmek için istihdam edilmiş bulunan askerlerin aslında hayat pahalılı̆̆ını aşabilecek kadar kazanamadıklarını ortaya koymaktadır. Askerlerin geçinmeğe iketidar yoktu. Çoğu ek iş yapmak zorundaydı. Öyle ki imparatorluğun çeşitli yerlerinde kale personelinin askerlik dışı ekonomik faaliyetlerini vergilendirmeye yönelik olarak hukuki düzenlemeler gerçekleştirilmişti. Bu açıdan adalarda yaratılan katma değer ve ekonomik hacmin potansiyeli askerlerin neredeyse hiçbirine ek iş olanağ1 da sunmuyordu. Bu durum istihdam süreçlerine yansıyor, komutanları tarafindan elde tutulmak istenen mahir askerler kaleleri terk ediyordu. Dahası ulufe usulsüzlükleri yaşanabiliyordu.

Tarihsel kayıtlar kaleyi, taştan ve harçtan çok yaşayan bir organizma gibi

sunar. Kendi mikrokozmosu içinde neferân ve zabitânın dişında mağduru, talihlisi, cesuru, mahiri her türden insanı içinde barındıran bir yapıydı. Kale, ancak ahenk içinde savaşan silah arkadaşlarının birlikte savunabileceği bir tahkimattı ve onu ayakta tutan, arızalarıyla, güçlü ve zayıf yönleriyle imparatorluk tarafindan kurgulanmış olan organizasyondu. Kalelere yüklenen stratejik sorumlulukların tabii bir sonucu olarak bu yapılanma, karşı karşıya kalınan sorunların tespitinde ve çözümünde reaksiyon gösterilmesini de olanaklı kıliyordu. Tarihsel tecrübe, sorunların askerî pragmatizmi merkeze alan bir yaklaşımla çözüme kavuşturulduğunu, ihtiyaçların doğru şekilde ortaya konulduğunu göstermektedir. Burada ortaya konulan örnek, imparatorluğun idari pratiklerine sonraki yüzyıllarda damgasını vuracak olan 1slahatçı ruhun muştulayıcısı gibidir. Yine de askerî harcamaların ağırlığ1 özellikle personelin geçim sıkıntısının mutlak bir şekilde çözüme kavuşturulmasina engel olmuştur. Usulsüzlükler ve ekonomik sorunlar Ege'deki Osmanlı kalelerinde görev yapan askerlerin Osmanlı Devleti'nin genelinde hatta imparatorluğun ekonomik ve siyasi olarak eklemlenmiş bulunduğu Akdeniz ve Avrupa'da yaşanan gelişmelerden etkilendiğini ortaya koymaktadır..

68 BOA.MAD.d. 7385 , s. 52-56. 


\section{Kaynaklar}

\section{Arşiv belgeleri:}

BOA (Cumhurbaşkanlığı Devlet Arşivleri Başkanlığı Osmanlı Aşivi).TT.d. (Tapu Tahrir Defteri Fonu) nr. (numara) 25, 75, 261, 264, 307, 367, 434, 594.

BOA.A.DVNSMHM.d. (Divan-1 Hümayun Sicilleri Mühimme Defterleri Fonu) nr. 8, 33, 45.

BOA.MAD.d. (Maliyeden Müdevver Defterler Fonu) nr. 233, 619, 731, 4378, 4634, 5228, 5683, 6166, 7186, 7365, 7385, 12760.

\section{Yayımlanmış arşiv belgeleri:}

12 Numaral Mübimme Defteri (978-979 / 1570-1572) <Özet-Transkripsiyon ve Indeks> (Haz. H. O. Yıldırım, V. Atik, M. Cebecioğlu vdğr.), Ankara 1996.

Barkan, Ömer Lütfi, XV ve XVinci Asırlarda Osmanl Imparatorluğunda Zirâ̂ Ekonominin Hukukî ve Malî Esaslar, I: Kanunlar, İstanbul 1943.

Sofyah Ali Cavus Kanunnamesi, (Haz. Mithat Sertoğlu), İstanbul 1992.

Şahin, İlhan, “Timar Sistemi Hakkında Bir Risale”, Tarih Dergisi, 32 (Mart 1979), s. 926.

\section{Muasır kaynaklar, araştırma ve inceleme eserler:}

Akdağ, Mustafa, Mustafa Akdağ, "Yeniçeri Ocak Nizamının Bozuluşu”, Ankara Üniversitesi Dil ve Tarih-Coğrafya Fakültesi Dergisi, 5/3 (1947), s. 291-313. Türkiye'nin İktisâdi ve İctimâ̂ Taribi, II (1453-1559), İstanbul 1979.

Beydilli, Kemal, "Yeniçeri”, DIA , Cilt 43, İstanbul 2013, s. 450-462.

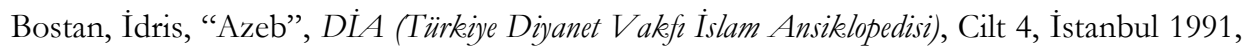
s. 311-312.

Braudel, Fernand, Spooner, Frank, "Prices in Europe from 1450 to 1750", The Cambridge Econonic History, Cilt IV (Ed. E. E. Rich, C. H. Wilson), Cambridge 1967, s. 378-486.

Bröckling, Ulrich, Disiplin: Askeri İtaat Üretiminin Sosyolojisi ve Taribi, (çev. Veysel Atayman), İstanbul 2008.

Celâl-zâde Mustafa, Selim-nâme, (Haz. A. Uğur, M. Çuhadar), Ankara 1990.

Danişmend, İsmail Hâmi, Osmanlı Devlet Erkân, İstanbul 1971.

Demircan, Yasemin, Tabrir Defterlerine Göre Boğazönü Adalar (XV ve XVII. Yüzyllar), Ankara Üniversitesi Sosyal Bilimler Enstitüsü Doktora Tezi, Ankara 1992. , Osmanl Idaresinde Limni Adası, Ankara 2014.

Ege Adalarmm Egemenlik Devri Tarihçesi, (ed. Cevdet Küçük), Ankara 2001.

Ege Adalar'nın İdarî, Malî ve Sosyal Yapısı, (ed. İdris Bostan), Ankara 2003.

Erdoğru, Mehmet Akif, Rodos'un Sosyal ve Ekonomik Taribi, İzmir 2018.

Feyzioğlu, Hamiyet Sezer, “III. Selim Dönemi’nde Humbara Ocağı'nda Yapılan Düzenlemeler”, Tarih Arastırmalar Dergisi, 35/60 (2016), s. 141 - 156.

Genç, Mehmet, Osmanl Imparatorluğunda Devlet ve Ekonomi, İstanbul 2010.

Gezer, Ömer, Kale ve Nefer. Habsburg Sinmnda Osmanl Askerî Gücünün Yeniden Örgütlenmesi (1699-1715), Hacettepe Üniversitesi Sosyal Bilimler Enstitüsü, Ankara 2016.

Haritalar ve Coğrafya Eserlerine Göre Ege Deniẓi ve Ege Adalar, (Ed. İdris Bostan, v.dğr.), Ankara 2003. 
Káldy-Nagy, Gyula, "The First Centuries of the Ottoman Military Organization", Acta Orientalia Academiae Scientiarum Hungaricae, 31/2 (1977), s. 147-183.

Kâtib Çelebi, Tubfetü'l-Kibâr fî Esfâri'l-Bihâr, (Haz. İdris Bostan), Ankara 2008.

Kütükoğlu, Mübahat, "Narh (Osmalılar'da)", Dذ̇A, Cilt 32, İstanbul 2006, s. 390-391.

Nalezen, Orcun, Ege Adalarnda Osmanl Hâkimiyetinin Kurulmasinda ve Sürdürülmesinde Kalelerin Rolü, Gazi Üniversitesi Sosyal Bilimler Enstitüsü, Doktora Tezi, Ankara 2021.

Nar, Mehmet Şükrü, “Jean-Jeacques Rousseau'nun Doğal Hukuk Anlayışı Üzerine Antropolojik Bir Değerlendirme”, Bilgi, 30 (2015 Yaz), s. 42-68.

Özcan, Abdülkadir, "Humbaracı Ahmed Paşa", DLA, Cilt 18, İstanbul 1998, s. 351-353.

Özmucur, Süleyman, Pamuk, Şevket, "Real Wages and Standards of Living in the Ottoman Empire, 1489-1914, The Journal of Economic History, 62/2 (2002), s. 293-321.

Pamuk, Şevket, A Monetary History of the Ottoman Empire, Cambridge 2003.

Sennett, Richard, Otorite, (çev. Kamil Durand), İstanbul 2014.

Şakiroğlu, Mahmut H., "Cigalazâde Sinan Paşa”, DİA, Cilt 7, İstanbul 1993, s. 525-526.

Türk Hâkimiyetinde Ege Adaları'nın Yönetimi, (ed. Cevdet Küçük), Ankara 2002.

Unat, Faik Reşit, "Sadrazam Kemankeş Kara Mustafa Paşa Lâyihası", Tarih Vesikealar, 6/1 (Nisan 1642), s. 443-480.

Uzunçarşılı, İsmail Hakkı, Osmanlı Devleti Teşkilâtından Kapıkulu Ocaklar, I: Acemi Ocağı ve Yeniçeri Ocağı, Ankara 1988.

Ünal, Ayhan Afşın, (XVI. Yüzxylda Cezair-i Bahr-i Sefid Eyaleti’nde) Midilli Sancăğ, Erciyes Üniversitesi Sosyal Bilimler Enstitüsü, Doktora Tezi, Kayseri 2002.

Von Clausevitz, Carl On War, (çev. Michael Howard, Peter Paret), Oxford 2007.

Yaşar Keskin, Filiz, Bir Osmanl Adasında Toplum ve Ekonomi (XVI. Yüzynldan XVIII. Yüzynla Sakıə), Hacettepe Üniversitesi Sosyal Bilimler Enstitüsü Doktora Tezi, Ankara 2013. 


\section{Summary}

The Ottoman fortresses in the Aegean Islands were a part of the defence structure covering the Eastern Mediterranean in the context of the Mediterranean-scale policies of the Ottoman Empire. The castles in question were located on the islands from Bozcaada to Rhodes and lined up along the western coast of Anatolia on a north-south axis. Soldiers serving in the castles had a salaried status (ulufeli). The financial resources of the soldiers' salaries were provided in the area that defended by the castles. In other words, the soldiers not only defended the imperial frontier but also defended the resources that provided their wages. However, problems and illegal practices of the kind that were seen almost everywhere throughout the empire were also encountered in the Aegean Islands. Soldiers were rarely able to receive their salaries on time. In some cases, they were illegally losing their position in the castle. Some of them were earning unfairly more income. More importantly, they were suffering from financial difficulties. The livelihood had reached such a level that the records reveal that there were no volunteers to serve in the castles. The fortifications could not be deployed as many soldiers as would be needed for effective defence.

The main reason for the soldiers' difficulty in making a living was the high inflation seen throughout the Mediterranean. On the other hand, from the second half of the 15 th century to the 17 th century, it is seen that the salaries of the soldiers did not change at all. However, in this period, there was an increase of up to $119 \%$ in the prices of basic necessities, which are constantly consumed in order to sustain daily life, due to inflation. Historical records show that especially the soldiers who served in the Ottoman castles tried to make a living through some non-military activities. It is seen that some of the soldiers who served in various parts of the empire were engaged in agriculture and animal husbandry, and accordingly they were taxpayers. On the other hand, it is understood that the soldiers serving in the castles in the Aegean lack such opportunities. Obviously, the limited economic capacity of the Aegean Islands did not offer enough job opportunities to the soldiers. Regardless, the Aegean Islands constituted one of the areas where the Ottoman Empire faced its traditional rivals, the Catholic Western powers. The troops, ready to withstand a comprehensive attack at any moment, had to be stationed in the fortresses of the Aegean Islands.

The relationship between the obedience of the soldier and the regular payment of the soldiers' salaries were well known because of the military uprisings that took place starting from the 15th century. The soldiers in the Aegean Islands did not have the potential to initiate bloody and extensive uprisings. Instead of rebelling, they expected grace and charity from the state. In cases where these demands were not met, they had no choice but to leave the castles. In summary, there was a natural balance between the military's desire to fight and the salary policy. In the Aegean Islands, this balance was disturbed due to economic problems. The resulting defensive weakness was noticed after a while. Kaptanpaşa, who is the most authorized administrative-military chief of the Mediterranean Islands Province (Cezayiri Bahr-i Sefid), which includes the Aegean Islands, took action. First of all, it 
was necessary to improve the salaries of the soldiers. However, there were not enough resources available. As a result of the examination of the records and the counts, it was determined that some soldiers were paid much more than they deserved. For example, it was understood that some of the soldiers who did not have any command duty earned 13 akce per day, while others were trying to live on a daily income of 5 akce. Moreover, it was noticed that the castles were only defended by soldiers who took less than they deserved. In the face of this situation, the surplus in the salaries of the soldiers with more income was added to the salaries of the soldiers who earned less, and income justice was achieved. It is understood that with this exceptional solution, justice is tried to be provided between the soldiers. On the other hand, it is seen that the decisions taken do not address the root of the problem, and no action is taken to punish those who pave the way for income injustice and benefit from it. Obviously, the kaptanpaşa, who was essentially a soldier, acted without disturbing the officials who had a say in the administrative sense, without causing new tensions and exhibited a pragmatic attitude. Its purpose was to retain the human resources to enable the castles to be defended effectively. There is enough historical record to think that it did, at least for a time. 